\title{
The Impact of Store Environment on Consumer Behavior
}

\author{
E. Shirin Hima Bindu ${ }^{1 *}$, Swetha Kodali ${ }^{2}$ and D. Ratna Kumari ${ }^{1}$ \\ ${ }^{1}$ Department of RMCS, College of Community Science, PJTSAU, Saifabad, Hyderabad-04, \\ Telangana, India \\ ${ }^{2}$ Department of FRM, AICRP-WIA, PG and RC, PJTSAU, Rajendranagar, Hyderabd-30, \\ Telangana, India \\ *Corresponding author
}

\section{A B S T R A C T}

\section{Keywords}

Consumer

Behaviour, Store

Design, Store

Environment, Retail

store,

Merchandising

Article Info

Accepted:

15 January 2021

Available Online:

10 February 2021
An increasingly competitive global retail industry needs businesses to rethink their strategies for marketing and sales. In particular, the substantial rise in online purchases has helped to concentrate retailers' attention on all aspects of on-the-ground consumer sales. This paper explores the growing significance of consumer actions in the store setting and experiences. This paper analyzes recent research on the environmental impacts of stores on consumer behaviors. A purchaser who is interested in buying products and excited about their shopping experience will stay longer, spend more money and delights in it while coming back. The quantity and quality of illumination, the impression it creates concerning the merchandise and also its impact on the retail areas appearance are all factors for successful sale. A consumer interested in purchasing goods and enthusiastic about their shopping trip will linger longer, spend more cash and enjoy it while returning. All reasons for good sales are the quantity and quality of lighting, the feeling it produces about the merchandise and also its effect on the appearance of the retail areas.

\section{Introduction}

Consumer behaviour is a complex topic and one that has generated considerable research as firms look to develop global markets in an increasingly competitive environment (Czinkota and Ronkainen, 2013). A key complexity relates to the fact that each individual has their own shopping process and this process is based on a number of dynamic variables. A recent survey has identified increased support and sales suggest that faceto-face interaction with knowledgeable helpful sales staff is a key to their selecting their form of retail experience. As a result, understanding the in-store dynamics and factors that are in 
demand by consumers remain critically important for retailers. These factors can be internal or external. While internal factors originate from characteristic of the individual, external factors include culture and groups to which the individual identifies with, including households.

A store's physical atmosphere consists of different components, including which includes music, decoration, art, directional signs and human elements, often separated into an exterior and internal atmosphere that is external and internal to a shop. However these elements affect consumer behavior through their effect on the emotion, cognition and physiological condition of shoppers.

Despite this critical professional touch, retailers continue to strive to find ways to affect as many customers as possible and their respective decision-making processes. Retailers also try to manipulate the exterior design and location, the general interior, the internal layout of the shop, and the unique interior displays. Features of these fundamentals may have a huge effect on consumer behaviour. For example, storefront implies the image of the store, colours influence consumer's perception of the store, layout of the store needs to correspond to the type of store, and choosing the right interior layout is important for presenting the merchandise in the best possible light relative to the competition.

Many studies have examined which factors affect consumer behavior and how researchers have been very innovative in terms of finding ways to influence people's shopping choices. Among others, music manipulation, smell, interior, store crowding, brand, store name, and price discounts have been investigated.

The findings show that all the factors mentioned affect consumer behaviour in some way. Keller (2007) suggests that its personal importance and the accuracy with which it is portrayed over time are two factors that reinforce the connection to any piece of knowledge. Keller (2007) considers the two components of brand information to be brand image and brand perception (brand recall and recognition).

The store environment affects different phases of the cognitive process of shoppers inside a store, including focus, interpretation, categorization and processing of information. It has been shown, for instance, the perceived waiting time changes with the importance of music and the description of a restaurant as a fast food source by customers depends largely on the shop's external appearance. The influence of store environment on these cognitive stages will subsequently affect assessments of the store, its product and service, and hence on the shopping behaviors or outcomes.

In addition, the mediating role of cognition and emotions in the correlation between the retail environment and shopping preferences is evidenced by previous studies. In the relationship between the direct effect of the store environment and the mediating position of physiological states the store environment and shopping behaviors have not been examined by any research, however. Also, no research has empirically explored the effects of the transfer of meaning from the store setting to the products of a store.

None of the analysis has concurrently analyzed the different impacts of the store environment, with the example of Donovan et al., (1994), so our knowledge of the particular contribution of each type of influence is very minimal. Many environmental factors can have several effects on shopping habits. For example, lighting may affect the visual acuity of displayed objects and the arousal 
experienced by shoppers (Areni and Kim 1993). Human beings may have an innate reaction to the contrast between dark and light. In comparison, certain elements can primarily affect shopping behaviors through a specific route like background color can mainly affect shopping behaviors.

Causative factors or variables in the environment can have multiple implications on consumer patterns and these impacts on purchase habits differ from one variable to another. In particular, the product show of the following proposals on specific elements and results that affect the cognitions and emotions of shoppers in a store setting would be worth studying.

Without a significant influence on their feelings, cognitions or physiological state, a store layout may affect the behavior of shoppers inside a store. A store's lighting state will influence shoppers' emotions and some circumstances; however, it can also generate direct responses from shoppers. The lighting condition of a store can affect the feelings of shoppers, attention to and evaluation of the products of the store, and thus their behavior within the store. However, it may also cause direct reactions from shoppers in certain situations.

\section{Congruence issues}

The coherence between environmental factors will significantly promote the categorization of a retail outlet by consumers. For instance, customers can easily believe that the outlet is a high-class store when both the environmental and design conditions project a prestige image. As Categorization and assessment were always intertwined and congruence may often magnify the influence of these factors on product evaluation (Cohen and Basu 1987).This magnifying effect may also manifest as a positive effect of interaction between the components/factors of shopping behaviors or the variables of internal reaction emotions and cognition. However, only two studies have examined this problem of congruence (Baker et al., 1992; Baker and Grewal 1994). If the store's environmental elements / influences

They are congruent with each other and their effect on emotions, knowledge and shopping habits would be magnified. For instance, if both the environmental and architecture variables project a credibility image, their resulting effect on the appraisal of the store and its goods by shoppers will be greater than the sum of their individual impacts.

\section{Store background music}

Music is considered as an important element of store atmosphere which directly influences consumer buying behavior (Levy and Weitz, 2002). Matilla and Wirtz (2001) discovered that music can influence on impulse behavior as well. Music is regarded as an essential component of the store environment that directly affects customer purchasing behaviour (Levy and Weitz, 2002). Matilla and Wirtz (2001) found that music can also affect the actions of impulses.

\section{Store scent}

As well as music, store aroma often directly affects the emotions and moods of customers (Levy and Weitz, 2002). The shop's pleasant aura encourages customers to spend more time browsing at merchandise, which can contribute to purchasing urges. In the research of Matilla and Wirtz (2008) and Mohan, the effect of store smell on impulse purchasing behavior was established.

Retailers use innovative features to affect customer behavior in their store's physical environment. In consumer buying decisions, 
this factor can be very powerful, making it an important marketing tool for retailers (Kotler, 1973).

The customer is the central economic entity of an economy. In order to maximise satisfaction and utility, all customers purchase goods and services directly and indirectly. Consumers have minimal income and want to achieve their full utility by (utility is the want satisfying capacity of a commodity).Consumer behavior lets businesses determine what goods and services to create or offer. Organizations will more quickly spot a need that has not yet been met because they know what consumers want and how they go about purchasing those goods.

\section{Role of the consumer in determining the price}

The price of a commodity is determined by the rule of supply and demand. Consumers have a desire to buy a commodity, and to satisfy this demand, manufacturers generate a supply. A good's equilibrium market price is the price at which the quantity supplied corresponds to the quantity ordered. Store environmental effects on buying habits and the desire to return and improve the opportunity for satisfaction in order to appreciate the impacts of brand experience, such as atmospheric odor, luminosity and style.

While we are facing an economic recession and there is no doubt that this environment is shifting shopping habits, products and stores do have potential and consumers can continue to adapt and shops will grow with them (Faria, 2012). Beyond observing the economic process, understanding the current market and its different areas of trade must go beyond implementing marketing strategies that include the manufacture and distribution of consumer products or services.
Hawkins and Coney (2001) observed that both public and private intake systems are influenced by customer behaviour experiments. Other authors prefer to classify consumer behavior analysis as the collection of physical and mental behaviors carried out by consumers as a result of their choices, the way in which products and services are checked, selected, purchased and used to meet a latent need (Ehrenber et al., 1990; Engel, 1984), as a result of some stimulating factors (Turley and Milliman, 2000; Michon et al., 2005).

\section{Layout}

In five categories, Berman and Evans (1995) sought to present ambient stimuli that defined the shop's exterior, the general interior, the architecture, the decoration and the human variables, the general interior, the layout and human variables play a significant role for these writers in the happiness of consumers. According to these novelists, it is very important for managers to change the atmospheric elements whether they aim to communicate a certain picture to a certain segment or target group and thereby provoke certain customer behavior.

A consumer is the one who can determine whether to buy an item at the store or not, and someone who can be affected by the image of the store and advertisements. The effect of visual merchandising, particularly in relation to shop windows, on the gender based purchasing behavior of consumers and on the storage of attributes was most valued by consumers.

According to the merchandising methods used in shop window displays, the findings of the research carried out had revealed that the variations in store attributes was valued by customers in their purchasing behaviour. 


\section{References}

Areni, Charles S and Kim. 1993. "The Influence of In-store Lighting on Consumers' Examination of Merchandise in a Wine Store," International Journal of Research in Marketing, 11, 117-125.

Baker, J., Grewal, D and Parasuraman, A. 1994. The Influence of Store Environment on Quality Inferences and Store Image. Journal of the Academy of Marketing Science. 22:4, 328-339.

http://doi.org/10.1177/0092070394224 002.

Baker, Julie, Michael Levy and Dhruv Grewal. 1992. "An Experimental Approach to Making Retail Store Environment"

Griffitt, William (1970), "Environmental Effects on Interpertal Decisions," Journal of Retailing, 68:4, 445-60.

Berman, B., \& Evans, J. R. 1995. Retail management : A Strategic Approach. Retail management : A Strategic Approach. Journal the impact of store environment and shopping behaviour\& loyalty.

Cohen, Joel B. and Kunal Basu. 1987, "Alternative Models of Catcgorization: Toward a Contingent Processing Frame work," Journal of Consumer Research, 13 (March), 455-72.

Czinkotaand Ronkainen.2013.The impact of the in store environment on consumer behavior. Manager's Journal on Management, Vol. 14.1.

Donovan, R. J., and Rossiter, J. R. 1994. Store atmosphere: An environmental psychology approach. Journal of Retailing, 58(1), 35-5

Engel 1984. Ehrenberg 1990 International Journal of Market Research Vol. 50 Issue 4
Faria, 2012. "Environmental Effects on Interpersonal Affective Behavior: Ambient Temperature and Attraction," Journal of Personality and Social Psychology, 15:3, 240-44.

Evans (1995), "The Impact of Music on Consumers' Reactions to Waiting for Services," Journal of Retailing, 73:1, 87-104.

Hawkins, Roger J. Best, Kenneth A. Coney. Irwin/McGraw Hill, 2001 consumer behavior including psychological, social, and managerial implications. The new Delhi I. - Business \& Economics - 775 pages.

Kotler.1973. Atmospherics as a Marketing Tool. Journal of Retailing, 49:4, 4865.

http://doi.org/10.1016/j.obhdp.2011.03 .002

Levy, Michael and Barton A. Weitz 1998, Retailing Management, 3rd ed., Chicago: Irwin McGraw-Hill, Chapter 18, 54069 .

Levy, M. and B. A. Weitz. 2002. "Retailing Management New York." America: McGraw-Hill/Irwin

Mattila, A. S.and L. Hanks. 2004. antecedents to participation in corporate social responsibility programs. Journal of service management, 23:5, 664-676.

Mattila, B. A. S and Wirtz, J. 2008 antecedents to participation in corporate social responsibility programs. Journal of service management

Mohan, G., et al., 2013. Impact of store environment on impulse buying behavior. European Journal of Marketing 47(10): 1711-1732

Mattila, B. A. S. and Wirtz, J.2001. AnnaCongruency of Scent and Music As a Driver of in Store Evaluation and Behavior. Journal of Retailing, 77:2, 273-289 
Parasuraman, A., Leonard L. Berry, and Valerie A. Zeithaml. 1991. "Refinement and Reassessment of the SERVQUAL Scale," Journal of Retailing, 67: 4, 420-50.

Parasuraman, A., Valerie A. Zeithaml, and Leonard L. Berry (1988), "Servqual: A Multiple-Item Scale for Measuring Consumer Perceptions of Service
Quality," Journal of Retailing, 64:1, $12-46$.

Keller 2007 Journal on management https://www.acrwebsite.org/volumes/ $8468 /$ vol.

Turley and Miliiman 2005, Journal the impact of store environment and shopping behavior \& loyalty.73:1, 87-104.

\section{How to cite this article:}

Shirin Hima Bindu, E., Swetha Kodali and Ratna Kumari, D. 2021. The Impact of Store Environment on Consumer Behavior. Int.J.Curr.Microbiol.App.Sci. 10(02): 1739-1744. doi: https://doi.org/10.20546/ijcmas.2021.1002.205 